\title{
Effects of activin on hormone secretion by single female rat pituitary cells: analysis by cell immunoblot assay
}

\author{
S Miyamoto, M Irahara, K Ushigoe, A Kuwahara, H Sugino ${ }^{1}$ and \\ T Aono
}

Department of Obstetrics and Gynecology, School of Medicine, University of Tokushima, Tokushima 770-8503, Japan

${ }^{1}$ Institute for Enzyme Research, University of Tokushima, Tokushima 770-8503, Japan

(Requests for offprints should be addressed to S Miyamoto, Department of Obstetrics and Gynecology, School of Medicine, University of Tokushima,

3-18-15 Kuramoto-cho, Tokushima 770-8503, Japan)

\begin{abstract}
We investigated the effect of activin A on secretion of $\mathrm{LH}$, $\mathrm{FSH}$, and prolactin (PRL) by female cultured rat pituitary cells at the single-cell level by means of the cell immunoblot assay. Anterior pituitary cells from 8-week-old female rats were preincubated with or without activin A for $24 \mathrm{~h}$, after which they were monodispersed and immediately used for cell immunoblot assay.

The percentages of LH-, FSH- and PRLimmunoreactive cell blots detected were 5.5, 5.3 and $43 \cdot 1 \%$, respectively, of all pituitary cells applied to the transfer membrane. The percentage of LH-secreting cells and mean LH secretion per cell did not change after treatment with activin. In contrast, activin significantly
\end{abstract}

increased the percentage of FSH-secreting cells and mean FSH secretion per cell to $136 \cdot 0$ and $114.5 \%$ respectively. In addition, activin significantly decreased the percentage of PRL-secreting cells and mean PRL secretion per cell to $52 \cdot 2$ and $72 \cdot 0 \%$ respectively.

These results suggest that (1) activin A has effects on female rat pituitary cells that increase not only the amount of FSH secretion per cell but also the number of FSHsecreting cells, and (2) activin A decreases both the amount of PRL secretion per cell and the number of PRL-secreting cells.

Journal of Endocrinology (1999) 161, 375-382

\section{Introduction}

Originally isolated from the gonads, activin has been detected in the rat anterior pituitary (Meunier et al. 1988, Roberts et al. 1989, Bilezikjian et al. 1993, Halvorson et al. 1994, Liu et al. 1996), where it may play an autocrine/ paracrine role in the regulation of anterior pituitary hormones (Corrigan et al. 1991, Besecke et al. 1996). Recent studies have demonstrated that it has specific stimulatory effects on follicle-stimulating hormone (FSH) gene expression in the pituitary and FSH secretion in culture but has no effect with regard to luteinizing hormone (LH) (Vale et al. 1986, Ling et al. 1986, Kitaoka et al. 1987, Ying 1988). Attardi \& Miklos (1990) used static plated cultures and reported increased FSH secretion in activin-treated male rat pituitary. Katayama et al.(1990), on the other hand, in an immunocytochemical study showed that treatment with activin $\mathrm{A}$ increases the number of immunoreactive FSH-containing cells in male rat pituitary cell cultures without affecting the proportion of immunoreactive LH-containing cells. Activin has also been shown to inhibit secretion of prolactin (PRL), growth hormone (Kitaoka et al. 1988, Murata \& Ying 1991) and adrenocorticotropic hormone (Bilezikjian et al. 1991) in culture.
Recent improvements in techniques, such as the cell immunoblot assay (CIBA) (Kendall \& Hymer 1987, Arita et al. 1991, Arita 1994) and the reverse hemolytic plaque assay (Neill \& Frawley 1983), have made it possible to quantify the amount of hormones secreted by individual endocrine cells and to estimate the relative abundance of hormone-secreting cells. The results of such analyses at the single-cell level have suggested that endocrine cells that secrete a specific hormone are functionally heterogeneous with respect to both basal and secretagogue-induced secretion.

The objectives of the present study were to investigate how activin A changes the secretions of FSH and PRL in cultured pituitary cells. For this purpose, we analyzed the effects of activin A on LH, FSH, and PRL secretion by cultured female rat pituitary cells at the single-cell level by using the chamber CIBA technique.

\section{Materials and Methods}

\section{Reagents}

Recombinant human activin A was a gift from the Central Research Laboratory of Ajinomoto Co. (Kawasaki, Japan) 
(Eto et al. 1987). Dulbecco's modified Eagle's medium (DMEM) with Hepes buffer (DMEMH) and PBS with Hepes buffer (PBSH) were prepared from powdered DMEM (Nissui, Tokyo, Japan), powdered Dulbecco's PBS (Nissui), $\mathrm{NaHCO}_{3}(1 \cdot 8 \mathrm{~g} /$ liter), penicillin G (100 U/ $\mathrm{ml})$, streptomycin sulfate $(100 \mu \mathrm{g} / \mathrm{ml})$ and Hepes $(20 \mathrm{mM})$. Fetal calf serum and horse serum were purchased from Filtron Pty Ltd (Brooklyn, Victoria, Australia) and heat-inactivated before use. The rat LH, FSH and PRL (rat LH RP-3, rat FSH RP-2 and rat PRL RP-3 respectively) used as the standards in the CIBA were generously provided by the NIADDK. Rabbit antiserum to rat $\mathrm{LH}(\mathrm{A} 536 / \mathrm{R} 4 \mathrm{H})$ and rabbit antiserum to rat PRL (i539/002) were purchased from UCB-bioproducts S A (Braine-Alleud, Belgium). Rabbit antiserum to rat FSH (anti-rat FSH-IC-1) was obtained through the National Hormone and Pituitary Program of the NIDDK (Bethesda, MD, USA). Biotinylated donkey anti-rabbit immunoglobulin antibody and streptavidin-alkaline phosphatase conjugate were purchased from Amersham (Arlington Heights, IL, USA). Trypsin 1:250 and pancreatin were purchased from Sigma (St Louis, MO, USA). BSA (fraction V) and the chemicals used were obtained from Wako Pure Chemical Industries Co. Ltd (Osaka, Japan) unless otherwise specified.

\section{Rat female pituitary cell cultures}

All animal experimentation was conducted in accordance with the ethical standards of the institutional animal care and use committee of the University of Tokushima.

Eight-week-old female Wistar rats (Charles River Japan, Inc., Yokohama, Japan) at random stages of the estrous cycle were used. Dispersed anterior pituitary cells were prepared by trypsin digestion as described previously (Yokoyama et al. 1995), with some modifications. Anterior pituitaries were removed after decapitation and minced into small fragments. The fragments were incubated with shaking at $37^{\circ} \mathrm{C}$ for $40 \mathrm{~min}$ in freshly prepared solution containing $0 \cdot 25 \%(\mathrm{w} / \mathrm{v})$ trypsin $1: 250$ in $20 \mathrm{ml} 0 \cdot 3 \%$ $\mathrm{BSA} / \mathrm{PBSH}$, then mechanically dispersed with a Pasteur pipette and passed through a $100 \mu \mathrm{m}$ metal mesh until monodispersed cells were obtained. After incubation in solutions containing $0 \cdot 1 \%$ pancreatin for $1 \mathrm{~min}$ in $10 \mathrm{ml}$ $0 \cdot 3 \% \mathrm{BSA} / \mathrm{PBSH}$, the monodispersed cells were washed three times in DMEM with 2.5\% fetal calf serum and 10\% horse serum (DMEMS).

Cell yield per pituitary was $(2 \cdot 0-2 \cdot 5) \times 10^{6}$ cells, and cell viability, as judged by trypan blue exclusion, was more than $95 \%$. Pituitary cells were incubated at $37^{\circ} \mathrm{C}$ in a humidified atmosphere of $5 \% \mathrm{CO}_{2} / 95 \%$ air with fresh DMEMS with or without $10 \mathrm{nM}$ activin A at a density of $1.5 \times 10^{6}$ cells $/ 35 \mathrm{~mm}$ well. After $24 \mathrm{~h}$, the culture medium was removed and the cells were completely monodispersed with $0 \cdot 01 \%$ trypsin 1:250 and washed twice with
DMEMH. Cell yield per well was $(1 \cdot 2-1 \cdot 4) \times 10^{6}$ cells, and viability was more than $95 \%$.

\section{CIBA}

CIBA was performed by the method described previously (Arita 1994). In brief, pieces $(50 \times 25 \mathrm{~mm})$ of polyvinylidene difluoride transfer membrane (Immobilon; Millipore, Bedford, MA, USA) were prewetted in methanol for $20 \mathrm{~s}$, rinsed in distilled water for $5 \mathrm{~min}$, and equilibrated with DMEMH for $60 \mathrm{~min}$ before use in cell blotting. The prewetted transfer membrane was placed on a glass microscope slide with the water-repellent side up to form the floor of the chamber. Two small glass coverslips $(18 \times 24 \mathrm{~mm}$, thickness $0.14 \mathrm{~mm})$ were placed $20 \mathrm{~mm}$ apart on the transfer membrane, and a large glass coverslip $(60 \times 24 \mathrm{~mm})$ was then lowered on to the small glass coverslips to form the roof of the chamber. The incubation chamber had an area of $360 \mathrm{~mm}^{2}$, a height of $0.15 \mathrm{~mm}$, and an average volume of $54 \mu \mathrm{l}$. Then, $100 \mu \mathrm{l}$ of monodispersed pituitary cell suspension was infused into the chamber. Cell density was $1.5 \times 10^{6}$ cells $/ \mathrm{ml}$ in the CIBA for $\mathrm{LH}$ and $\mathrm{FSH}$, and $5 \times 10^{3}$ cells $/ \mathrm{ml}$ in the CIBA for PRL. The chambers were incubated at $37^{\circ} \mathrm{C}$ in a humidified atmosphere of $5 \% \mathrm{CO}_{2} / 95 \%$ air for 0.5 to $6 \mathrm{~h}$. Various amounts $(78 \cdot 125-2500 \mathrm{pg})$ of rat LH, FSH or PRL in $250 \mathrm{nl} 20 \mathrm{mM}$ Tris-buffered saline, $\mathrm{pH} 7 \cdot 6$ (TBS), supplemented with $0.8 \%$ Tween 20 , were applied as the standard on dry transfer membranes. After incubation for $30 \mathrm{~min}$, the transfer membranes for the standards were immersed and rocked in 100\% methanol for $10 \mathrm{~s}$, washed in distilled water and DMEMH for 2 and 10 min respectively, and then processed in exactly the same way as those for cell blots.

Transfer membranes incubated with pituitary cells or to which standards had been applied were immersed in TBS containing 10\% BSA for $2 \mathrm{~h}$ to block any unoccupied binding sites. After the blocking procedure, the anterior pituitary hormones bound to the transfer membranes were immunostained specifically with the following solutions at room temperature with shaking: (1) 10\% normal donkey serum (Chemicon, Temecula, CA, USA) in $50 \mathrm{mM}$ Tris- $\mathrm{HCl}, \mathrm{pH} 7 \cdot 6$, containing $500 \mathrm{mM} \mathrm{NaCl}, 0 \cdot 5 \%$ Tween 20, 1\% BSA and $0 \cdot 05 \% \mathrm{NaN}_{3}$ (hTBS-T) for $30 \mathrm{~min}$; (2) primary antiserum against the anterior pituitary hormone in hTBS-T containing 10\% normal donkey serum for $12 \mathrm{~h}$ (rabbit antisera to rat LH and PRL at a dilution of 1:10 000, and rabbit antiserum to rat FSH at a dilution of 1:2000); (3) biotinylated donkey anti-rabbit immunoglobulin in hTBS-T containing $10 \%$ normal donkey serum at a dilution of 1:500 for $40 \mathrm{~min}$; (4) streptavidin-alkaline phosphatase conjugate at a dilution of 1:3000 in hTBS-T for $40 \mathrm{~min}$; and (5) the enzyme substrate nitroblue tetrazolium $(0.4 \mathrm{mg} / \mathrm{ml})$ and 5 bromo-4-chloro-3-indolyl phosphate $(0 \cdot 2 \mathrm{mg} / \mathrm{ml}$; BRL, 
Gaithersburg, MD, USA) in $0.1 \mathrm{M}$ Tris $-\mathrm{HCl}(\mathrm{pH} 9 \cdot 5)$, containing $0 \cdot 1 \mathrm{M} \mathrm{NaCl}$ and $50 \mathrm{mM} \mathrm{MgCl}$ for 3-4 min. During each interval between treatments, the transfer membranes were rinsed several times in TBS containing 0.1\% Tween 20 for 30-60 min. After the color reaction, the transfer membranes were rinsed with distilled water for $15 \mathrm{~min}$ and allowed to dry in air.

These cell blots were demonstrated to be specific because (1) omission of the primary or secondary antiserum and replacement of the primary antiserum with normal rabbit serum of the same dilution produced no cell blots, and (2) preabsorption of the primary antiserum with $10 \mathrm{ng} / \mathrm{ml} \mathrm{rat} \mathrm{LH,} \mathrm{FSH} \mathrm{or} \mathrm{PRL} \mathrm{for} 48 \mathrm{~h}$ before use in the CIBA blocked formation of the cell blots.

\section{Image analysis}

The immunostained transfer membranes were photographed with a stereo microscope (SZ6045TR; Olympus, Tokyo, Japan) equipped with $35 \mathrm{~mm}$ photomicrography and a fiber-optic ring light system, and the amounts of anterior pituitary hormones secreted by single cells were quantified with a Macintosh computer (Apple Japan, Tokyo, Japan) using the public domain NIH Image program (NIH Image 1.62) by the following processes.

(1) Stained transfer membranes were illuminated with constant light, magnified with a stereo microscope, and then photographed with $35 \mathrm{~mm}$ films (Fujichrome 100; Fujifilm, Tokyo, Japan).

(2) The photomicrographs obtained were digitized with a $35 \mathrm{~mm}$ film scanner (QuickScan 35; Minolta, Tokyo, Japan) and saved as an array $(1920 \times 1266$ pixels $)$ of gray levels in TIFF format. The mean area of the LH and FSH blots was smaller than that of the PRL blots at the same magnification, so they were scanned at double magnifying power. For this reason, a pixel in the saved images corresponded to $2.69 \mu \mathrm{m}$ in actual distance in the $\mathrm{LH}$ and FSH analysis, and $5.38 \mu \mathrm{m}$ in the PRL analysis.

(3) After shading error correction, the gray values of cell blots based on the optical density of the saved images were converted to values based on the amount of each anterior pituitary hormone per pixel by referring to the standards.

(4) After the gray level of the background field neighboring the cell blot to be measured had been computed, the threshold value for the binary image was calculated by adding the value that corresponded to $2 \mathrm{fg} /$ pixel (usually $20-25)$ to the average gray value of the background field.

(5) Using the binary image, the area of cell blots was determined by computing the number of pixels above the threshold in each cell blot (usually 50-2000 pixels/cell blot).

(6) The amount of hormone secreted by single cells was calculated by multiplying the area of cell blots by the difference between the average gray value of the cell blots and the threshold value.
Statistical analysis

The number of hormone-secreting cells in a $5.2 \times 3.4 \mathrm{~mm}$ area of the incubation chamber in the LH and FSH analysis, and in a $10.3 \times 6.8 \mathrm{~mm}$ area in the PRL analysis, and the mean amounts of hormone secretion per cell were determined from five transfer membranes in each experiment, and the mean and s.E. values were calculated from the values in five independent experiments. Differences were statistically analyzed by ANOVA. In addition, $P<0.05$ was considered to be statistically significant.

\section{Results}

Photomicrograph and standard CIBA curves

Figure 1 shows a photomicrograph of rat anterior pituitary hormone-immunoreactive cell blots in a CIBA chamber with (Fig. 1, A-2, B-2 and C-2) and without (Fig. 1, A-1, B-1 and C-1) activin A. Activin A was effective in increasing FSH immunoreactivity (Fig. 1, B-1 and B-2) and in decreasing PRL immunoreactivity (Fig. 1, C-1 and C-2), but its presence did not alter LH immunoreactivity (Fig. 1, A-1 and A-2). The standard curves used in the CIBA for LH, FSH and PRL are shown in Fig. 2. Conversion of the gray level for the optical density of cell blots to the gray levels for the amount of LH, FSH or PRL by referring to the respective standard curves made it possible to quantify the amount of hormone secreted by single cells.

Time dependence of the number of hormone-secreting cells and amount of secretion by individual cells

The number of hormone-secreting cells, defined as the number of all immunoreactive cell blots detected in a $5.2 \times 3.4 \mathrm{~mm}$ area of the incubation chamber in the analysis for LH and FSH and in a $10.3 \times 6.8 \mathrm{~mm}$ area in the analysis for PRL, increased with incubation time and plateaued at between 1.5 and $6 \mathrm{~h}$ (Fig. 3). Accordingly, an incubation time of $3 \mathrm{~h}$ was chosen for use in the present study. The number of LH-, FSH- and PRLimmunoreactive cell blots detected after $3 \mathrm{~h}$ incubation accounted for $5 \cdot 5 \pm 0 \cdot 3,5 \cdot 3 \pm 0 \cdot 6$ and $43 \cdot 1 \pm 4 \cdot 4 \%$ respectively of the total number of pituitary cells applied to the transfer membrane.

Mean LH secretion and mean FSH secretion by individual cells increased with incubation time, with plateaus between 1.5 and $6 \mathrm{~h}$, while mean PRL secretion increased in a time-dependent manner up to $6 \mathrm{~h}$ (Fig. 3).

\section{Effect of activin on frequency distribution of hormone-} secreting cells

The frequency distribution of LH, FSH or PRL secretion by single cells during a $3 \mathrm{~h}$ incubation was compared 
A -1

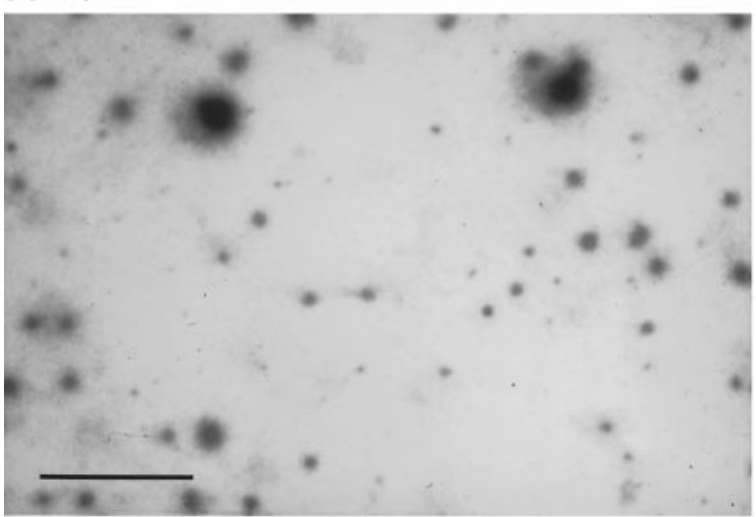

B - 1

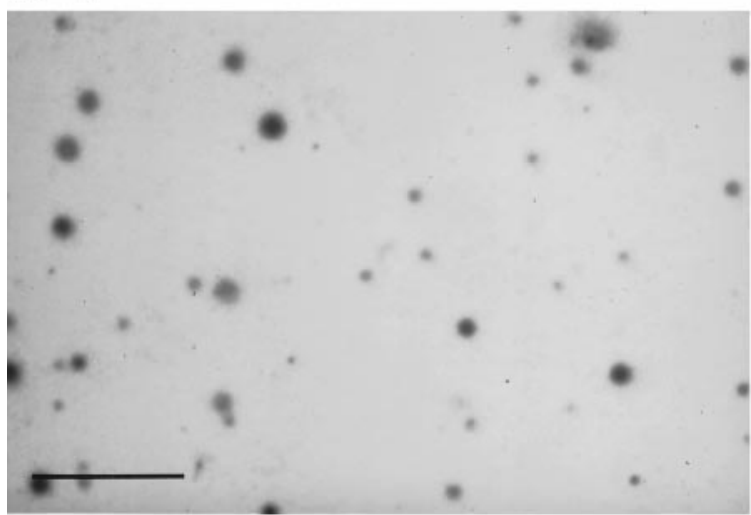

C - 1

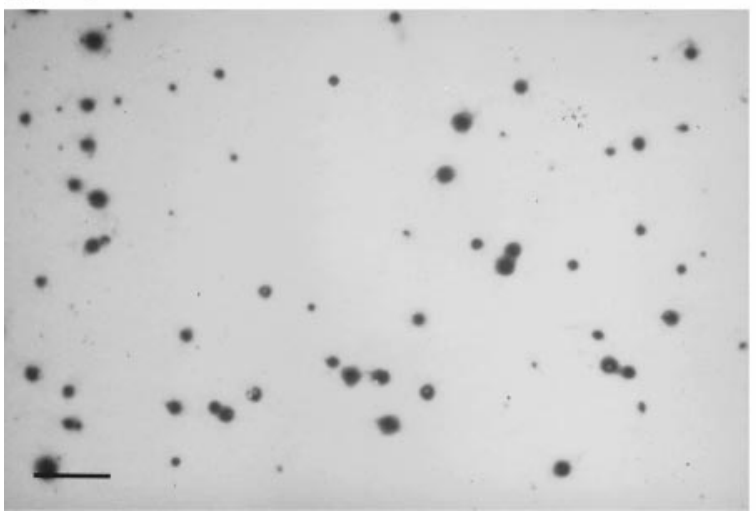

A - 2

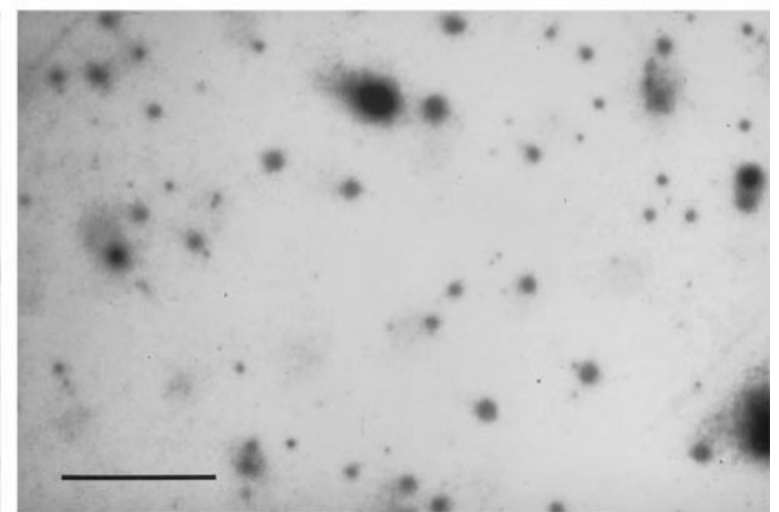

B - 2

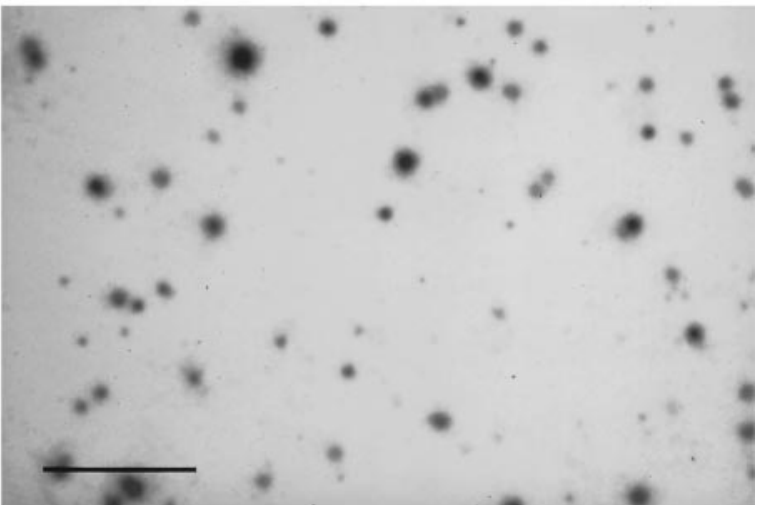

C - 2

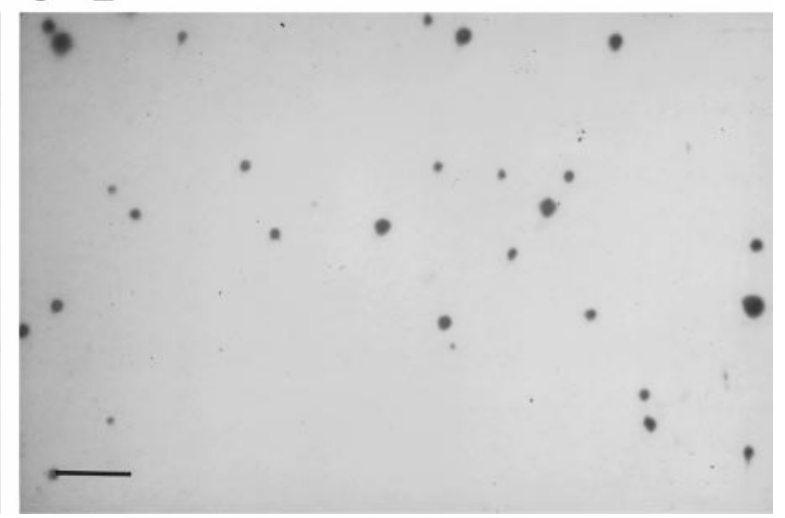

Figure 1 Photomicrographs of representative anterior pituitary hormone-immunoreactive cell blots. (A) LH, (B) FSH, (C) PRL, (1) no treatment and (2) treatment with $10 \mathrm{nM}$ activin A. Bar=500 $\mu \mathrm{m}$.

between control and activin-pretreated cells (Fig. 4). The amount of $\mathrm{LH}$ secretion by single cells varied from 0.03 to $31.37 \mathrm{pg} /$ cell per $3 \mathrm{~h}$ in the control group. More than $90 \%$ of the total LH-secreting cells secreted less than $1 \mathrm{pg} / 3 \mathrm{~h}$. No significant changes in LH secretion by individual cells occurred in response to the addition of activin, as shown in a representative sample in Fig. 1, A-2.
On the other hand, while the amount of FSH secretion by single cells varied from $0 \cdot 01$ to $25 \cdot 45 \mathrm{pg} /$ cell per $3 \mathrm{~h}$ in the control group, activin administration increased the number of FSH blots, as shown in a representative sample in Fig. 1, B-2.

By contrast, the amount of PRL secretion by single cells varied from 0.03 to $16.34 \mathrm{pg} /$ cell per $3 \mathrm{~h}$ in the control 


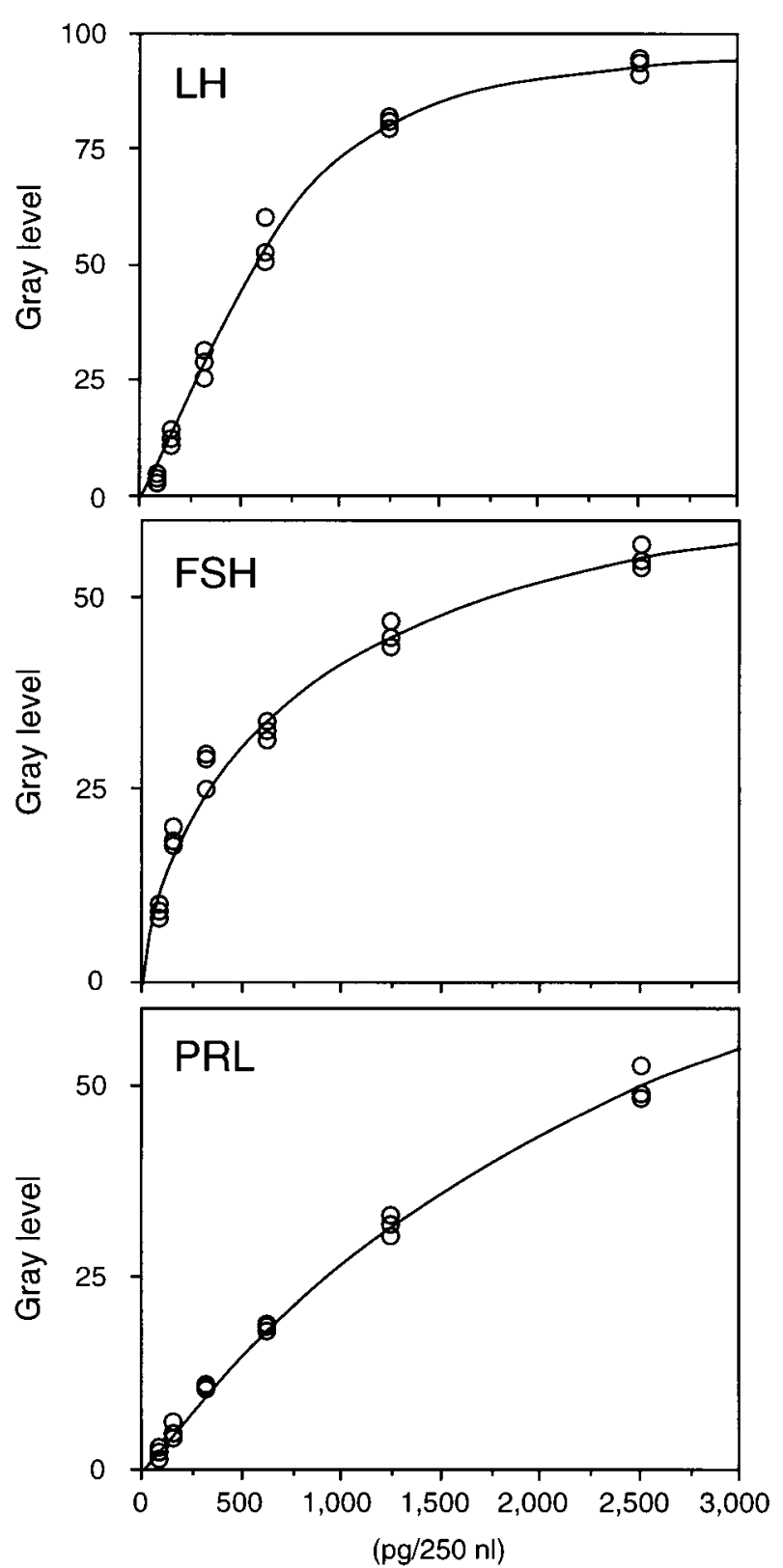

Figure 2 A standard curve used in the CIBA for LH, FSH and PRL. Various amounts of rat LH (NIADDK RP-3), FSH (NIADDK RP-2) or PRL (NIADDK RP-3) in $250 \mathrm{nl}$ TBS-T were applied to transfer membranes and immunostained by standard immunocytochemical procedures. The gray level on the ordinate was obtained by subtraction of the actual gray level of the standards from the gray level of the background. As the area of $\mathrm{LH}$-immunoreactive blots produced by applying the standard solution was approximately $8670000 \mu \mathrm{m}^{2}$ on average, an LH amount of $2500 \mathrm{pg} / 250 \mathrm{nl}$ solution on the abscissa, for example, corresponded to $288 \cdot 3 \mathrm{ag} / \mu \mathrm{m}^{2}$ of blots.

group, and addition of activin A caused marked suppression of PRL secretion by individual cells, as shown in a representative sample in Fig. 1, C-2.
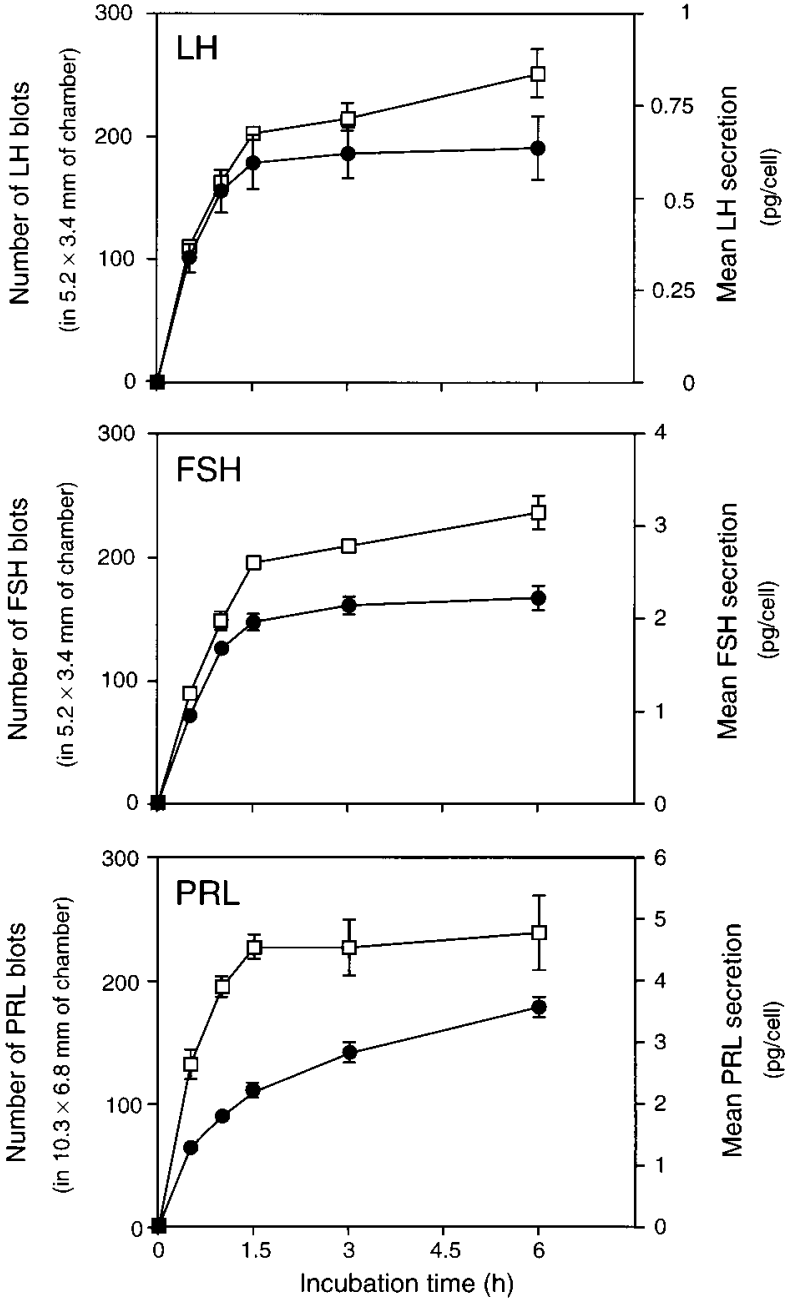

Figure $3 \mathrm{LH}, \mathrm{FSH}$ and PRL secretion from individual anterior pituitary cells as a function of incubation time. The number of all LH-, FSH- or PRL-immunoreactive blots that were detected in an area of $5.2 \times 3.4 \mathrm{~mm}(\mathrm{LH}$ and $\mathrm{FSH})$ or $10.3 \times 6.8 \mathrm{~mm}$ (PRL) of incubation chamber $(\square)$ and the mean amount of LH, FSH or PRL secreted from single pituitary cells expressed as $\mathrm{pg} / \mathrm{cell}(\bullet)$ were determined after $0 \cdot 5,1,1 \cdot 5,3$ and $6 \mathrm{~h}$ incubation. Values are the mean \pm S.E. of five transfer membranes.

Effect of activin on number of hormone-secreting cells, mean hormone secretion and total hormone secretion

The number of hormone-secreting cells, mean hormone secretion by single cells and total hormone secretion, calculated by multiplying the number of hormonesecreting cells by the mean hormone secretion by single cells during a $3 \mathrm{~h}$ incubation, were compared between control and activin-pretreated cells (Fig. 5). In the control group, the number of LH-secreting cells was almost identical with the number of FSH-secreting cells $(216 \cdot 0 \pm 11 \cdot 7$ vs $208 \cdot 6 \pm 2 \cdot 5, P=0 \cdot 63)$ (Fig. 5 , top). When activin was added, however, the number of LH-secreting 

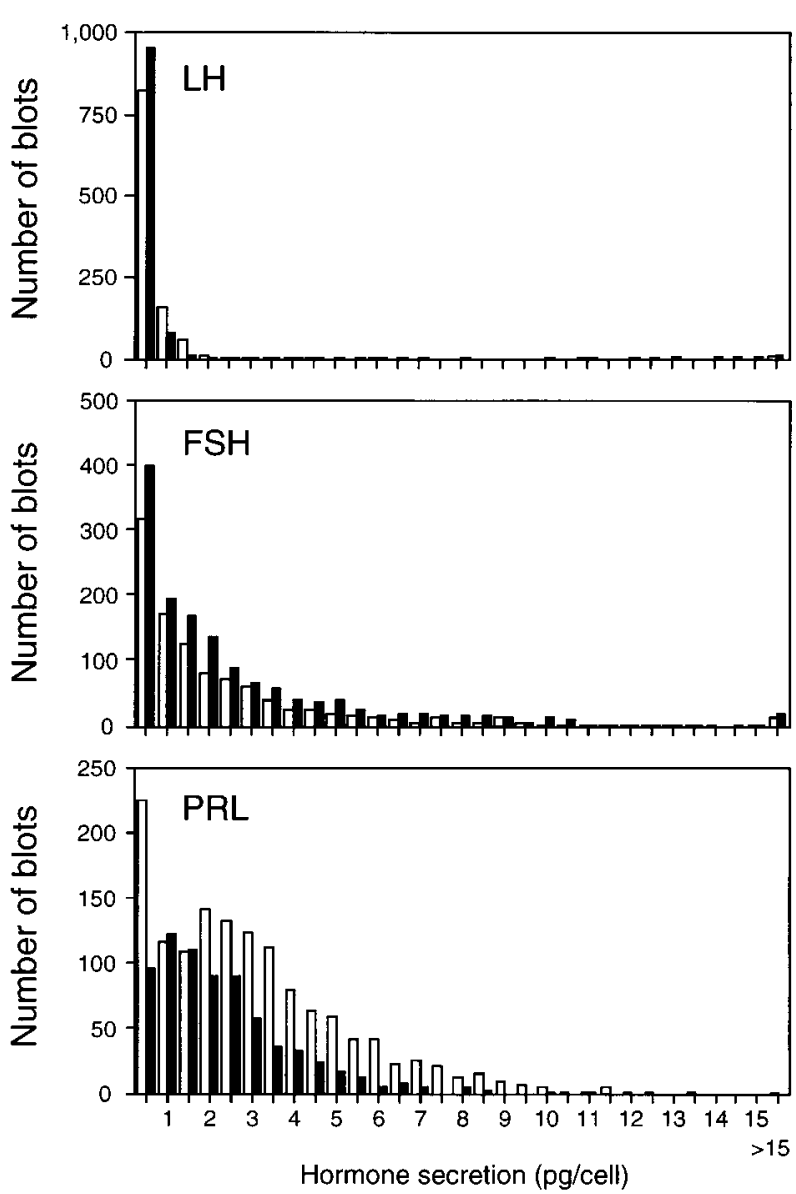

Figure 4 Frequency distribution of $\mathrm{LH}, \mathrm{FSH}$ and PRL secretion from single pituitary cells. Cells were maintained with either medium alone ( $\square$ ) or medium containing $10 \mathrm{nM}$ activin ( $\boldsymbol{\square}$ ) for $24 \mathrm{~h}$, and then used for CIBA. The range of each class is $0 \cdot 5 \mathrm{pg} /$ cell.

cells $(216 \cdot 0 \pm 11 \cdot 7$ vs $220 \cdot 0 \pm 16 \cdot 7, P=0 \cdot 76)$, mean $\mathrm{LH}$ secretion per cell $(0.62 \pm 0.07$ vs $0.68 \pm 0.08 \mathrm{pg}, P=0.56)$ and total LH secretion $(134.6 \pm 13 \cdot 0$ vs $148.5 \pm 13.4 \mathrm{pg}$, $P=0 \cdot 45$ ) did not change significantly (Fig. 5).

In contrast, administration of activin $\mathrm{A}$ resulted in a significant increase in the number of FSH-secreting cells, to $136 \cdot 0 \%(208 \cdot 6 \pm 2.5$ vs $283.6 \pm 8.7 \quad P<0 \cdot 01)$ (Fig. 5, top), and mean FSH secretion and total FSH secretion significantly increased, to $114.5 \%(2 \cdot 14 \pm 0.09$ vs $2.45 \pm 0.09 \mathrm{pg}, P<0.02)$ and $155.6 \%(446 \cdot 1 \pm 9.5$ vs $694 \cdot 0 \pm 17 \cdot 9 \mathrm{pg}, P<0 \cdot 01)$ respectively.

On the other hand, administration of activin A resulted in a significant decrease in the number of PRL-secreting cells, to $52 \cdot 2 \%(273 \cdot 3 \pm 27 \cdot 3$ vs $142 \cdot 7 \pm 12 \cdot 5, P<0 \cdot 01)$ (Fig. 5, top), and mean PRL secretion and total PRL secretion decreased significantly, to $72 \cdot 0 \%(2 \cdot 88 \pm 0 \cdot 07 \mathrm{vs}$ $2 \cdot 07 \pm 0.06 \mathrm{pg}, P<0 \cdot 01)$ and $37 \cdot 6 \%(785 \cdot 8 \pm 107 \cdot 1$ vs $295 \cdot 4 \pm 43 \cdot 1 \mathrm{pg}, P<0 \cdot 01)$ respectively.

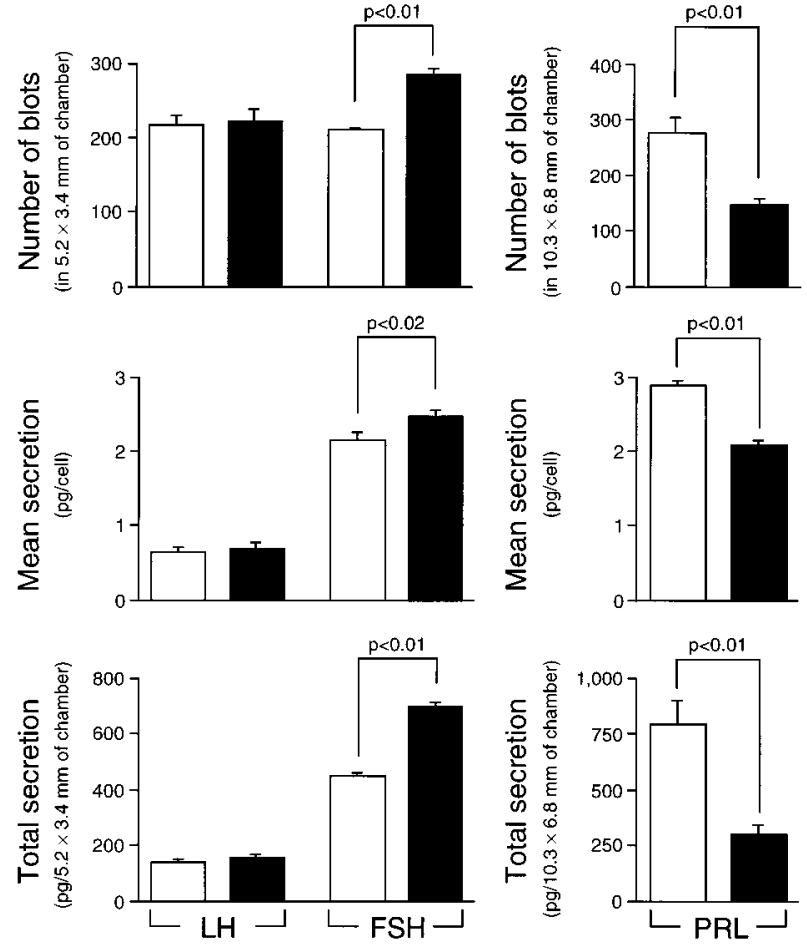

Figure 5 Effects of activin treatment on hormone secretion by individual anterior pituitary cells. Cells were maintained with either medium alone $(\square)$ or medium containing $10 \mathrm{nM}$ activin $(\boldsymbol{\square})$ for $24 \mathrm{~h}$, and then used for CIBA. The top panel shows the number of all $\mathrm{LH}$-, $\mathrm{FSH}$ - or PRL-immunoreactive blots that were detected in an area of $5.2 \times 3.4 \mathrm{~mm}(\mathrm{LH}$ and $\mathrm{FSH})$ or $10.3 \times 6.8 \mathrm{~mm}$ (PRL) of incubation chamber; the middle panel shows the mean amount of $\mathrm{LH}, \mathrm{FSH}$ or PRL secreted from single pituitary cells expressed as $\mathrm{pg} /$ cell; the bottom panel shows the total amount of $\mathrm{LH}, \mathrm{FSH}$ or PRL secretion obtained by multiplying the number of hormonesecreting cells by the mean hormone secretion. Values are mean \pm S.E. for five transfer membranes.

\section{Discussion}

CIBA using an incubation chamber makes it possible not only to quantify hormone secreted by single endocrine cells accurately but to determine simultaneously the percentage of hormone-secreting cells by counting immunoreactive cell blots detected in a given area of transfer membrane after incubation with cell suspension of a known cell density. Because of these advantages of chamber CIBA, we were able to investigate whether the increased FSH secretion and decreased PRL secretion in response to activin treatment in vitro were due to changes in the number of hormone-secreting cells and/or changes in the amount of hormone secreted per cell.

Approximately $5-6 \%$ of all pituitary cells were found to be LH- and FSH-secreting cells in the present study. Smith et al. (1984) have demonstrated that approximately $5-6 \%$ of all pituitary cells immunostained as LHcontaining cells, but that only some of these cells actually 
secrete LH, while Noguchi et al. (1996) reported finding that approximately $4-5 \%$ of all pituitary cells are FSHsecreting cells when CIBA was used. As LH and FSH are known to be secreted by the same cells under basal conditions, the present results are consistent with the findings in these earlier studies.

The present study has shown that LH and FSH are secreted quite heterogeneously by individual cells. The amount of LH secreted by single cells under basal conditions differs by approximately 1000-fold, and the corresponding amount of FSH differs by no less than 2000-fold. The finding that gonadotrophs are heterogeneous with respect to their FSH-secreting properties is consistent with the findings of Noguchi et al. (1996).

Using the CIBA for LH and FSH, the present study demonstrated that activin has the dual effect of increasing not only the percentage of gonadotrophs that actually secrete FSH but also the mean FSH secretion per cell, but that activin has no effect on the percentage of gonadotrophs that secrete LH or on mean LH secretion per cell, confirming a stimulatory action of activin on FSH secretion, with no effect on LH secretion in vitro (Vale et al. 1986, Ling et al. 1986, Kitaoka et al. 1987, Ying 1988).

Administration of activin A significantly increased the number of FSH-secreting cells, to $136 \cdot 0 \%$, but had no effect on the number of LH-secreting cells. This finding may mean that activin increases the proportion of FSHsecreting monohormonal cells without affecting the proportion of LH-FSH-secreting bihormonal cells. An immunocytochemical study by Katayama et al. (1990) showed that treatment with activin A $(10 \mathrm{ng} / \mathrm{ml})$ for $72 \mathrm{~h}$ increased the number of immunoreactive FSH-containing cells to $125-141 \%$ in male rat pituitary cell culture, but did not affect the proportion of immunoreactive LHcontaining cells. As the fact that a cell contains a particular hormone does not necessarily mean that it actually secretes it (Smith et al. 1984, Arita et al. 1993), our findings suggest that activin increases the number of FSH-secreting cells as well as the number of FSH-containing cells.

On the other hand, the use of CIBA for PRL in this study showed that activin decreases both the percentage of lactotrophs that actually secrete PRL and mean PRL secretion by individual cells, confirming the inhibitory action of activin on PRL secretion in vitro (Kitaoka et al. 1988, Murata \& Ying 1991).

Approximately $43 \%$ of all pituitary cells were demonstrated to be PRL-secreting cells in the present study. Boockfor \& Frawley (1987) demonstrated, using reverse hemolytic plaque assay, that approximately $40-50 \%$ of all pituitary cells are PRL-secreting cells, and Arita et al. (1991) demonstrated, using CIBA, that 55-66\% of all pituitary cells are PRL-secreting cells. One possible explanation for this difference in percentage of PRLsecreting cells may be the difference in time after trypsin dispersion. Arita et al. preincubated the pituitary cells for
8-9 days before using CIBA, whereas we preincubated them for $24 \mathrm{~h}$.

The present study has shown that PRL is secreted quite heterogeneously by individual cells. The amount of PRL secreted by individual cells differs by approximately 600-fold. The finding that lactotrophs are heterogeneous with respect to their PRL secretory properties is consistent with the findings of Arita et al. (1991).

Administration of activin A significantly decreased both the number of PRL-secreting cells and mean PRL secretion per cell, to $52 \cdot 2$ and $72.0 \%$ respectively in the present study. It has been reported that activin A reduces thyrotropin-releasing hormone-mediated (Kitaoka et al. 1988) and basal (Murata \& Ying 1991) PRL secretion in rat pituitary cell cultures. These reports, however, stated that activin A did not alter intracellular PRL content (Kitaoka et al. 1988) or that it increased it (Murata \& Ying 1991), and the immunocytochemical study by Katayama et al. (1990) suggested that activin A did not change the percentage of immunoreactive PRL-containing cells. This discrepancy between the effects of activin A on PRL-containing cells and PRL-secreting cells may suggest that activin regulates not only the production of PRL by pituitary cells but also its release.

In conclusion, our results suggest that (1) activin A has effects on female rat pituitary cells that increase not only the amount of FSH secretion per cell, but also the number of FSH-secreting cells, and (2) activin A also decreases both the amount of PRL secretion per cell and the number of PRL-secreting cells.

\section{Acknowledgements}

The authors are grateful to Dr Y Eto (Ajinomoto Co.) for his generous gift of human recombinant activin A. We also thank the NIADDK for providing the rat pituitary hormones for iodination and the NIDDK for providing the anti-rat FSH serum for immunocytochemistry. The public domain NIH Image program was written by Wayne Rasband at the US National Institutes of Health and is available on the Internet (http://rsb.info.nih.gov/ nih-image/).

\section{References}

Arita J 1994 Protein and peptide secretion from individual cells: measurement by cell immunoblot assay. Neuroprotocols $\mathbf{5} 250-263$.

Arita J, Kojima Y \& Kimura F 1991 Identification by the sequential cell immunoblot assay of a subpopulation of rat dopamineunresponsive lactotrophs. Endocrinology 128 1887-1894.

Arita J, Kojima Y \& Kimura F 1993 Measurement of the secretion of a small peptide at the single cell level by the cell immunoblot assay: thyroidectomy increases the number of substance P-secreting anterior pituitary cells. Endocrinology 132 2682-2688.

Attardi B \& Miklos J 1990 Rapid stimulatory effect of activin-A on messenger RNA encoding the follicle-stimulating hormone $\beta$-subunit in rat pituitary cell cultures. Molecular Endocrinology 4 721-726. 
Besecke LM, Guendner MJ, Schneyer AL, Bauer-Dantoin AC, Jameson JL \& Weiss J 1996 Gonadotropin-releasing hormone regulates follicle-stimulating hormone- $\beta$ gene expression through an activin/follistatin autocrine or paracrine loop. Endocrinology 137 3667-3673.

Bilezikjian LM, Blount AL, Campen CA, Gonzalez-Manchon C \& Vale W 1991 Activin-A inhibits POMC mRNA accumulation and ACTH secretion of AtT20 cells. Molecular Endocrinology $\mathbf{5}$ 1389-1395.

Bilezikjian LM, Vaughan JM \& Vale WW 1993 Characterization and the regulation of inhibin subunit proteins of cultured rat anterior pituitary cells. Endocrinology 133 2545-2553.

Boockfor FR, Frawley LS 1987 Functional variations among prolactin cells from different pituitary regions. Endocrinology 120 874-879.

Corrigan AZ, Bilezikjian LM, Carroll RS, Bald LN, Schmelzer CH, Fendly BM, Mason AJ, Chin WW, Schwall RH \& Vale W 1991 Evidence for an autocrine role of activin B within anterior pituitary cultures. Endocrinology 128 1682-1684.

Eto Y, Tsuji T, Takezawa M, Takano S, Yokokawa Y \& Shibai H 1987 Purification and characterization of erythroid differentiation factor (EDF) isolated from human leukemia cell line THP-1. Biochemical and Biophysical Research Communications 142 1095-1103.

Halvorson LM, Weiss J, Bauer-Dantoin AC \& Jameson JL 1994 Dynamic regulation of pituitary follistatin messenger ribonucleic acids during the rat estrous cycle. Endocrinology 134 1247-1253.

Katayama T, Shiota K \& Takahashi M 1990 Activin A increases the number of follicle-stimulating hormone cells in anterior pituitary cultures. Molecular and Cellular Endocrinology 69 179-185.

Kendall ME \& Hymer WC 1987 Cell blotting: a new approach to quantify hormone secretion from individual rat pituitary cells. Endocrinology 121 2260-2262.

Kitaoka M, Yamashita N, Eto Y, Shibai H \& Ogata E 1987 Stimulation of FSH release by erythroid differentiation factor (EDF). Biochemical and Biophysical Research Communications 146 1382-1385.

Kitaoka M, Kojima I \& Ogata E 1988 Activin-A: a modulator of multiple types of anterior pituitary cells. Biochemical and Biophysical Research Communications 157 48-54.

Ling N, Ying SY, Ueno N, Shimasaki S, Esch F, Hott M \& Guillemin R 1986 Pituitary FSH is released by a heterodimer of the beta-subunit from the two forms of inhibin. Nature 321 $779-782$.
Liu ZH, Shintani Y, Wakatsuki M, Sakamoto Y, Harada K, Zhang CY \& Saito S 1996 Regulation of immunoreactive activin A secretion from cultured rat anterior pituitary cells. Endocrine Journal 43 39-44.

Meunier H, Rivier C, Evans RM \& Vale W 1988 Gonadal and extragonadal expression of inhibin $\alpha, \beta \mathrm{A}, \beta \mathrm{B}$ subunits in various tissues predicts diverse functions. Proceedings of the National Academy of Sciences of the USA 85 247-251.

Murata T \& Ying SY 1991 Transforming growth factor- $\beta$ and activin inhibit basal secretion of prolactin in a pituitary monolayer culture system. Proceedings of the Society for Experimental Biology and Medicine 198 599-605.

Neill JD \& Frawley LS 1983 Detection of hormone release from individual cells in mixed populations using a reverse hemolytic plaque assay. Endocrinology 112 1135-1137.

Noguchi K, Arita J, Nagamoto A, Hosaka M \& Kimura F 1996 A quantitative analysis of testosterone action on FSH secretion from individual pituitary cells using the cell immunoblot assay. Journal of Endocrinology 148 427-433.

Roberts V, Meunier H, Vaughan J, Rivier J, Rivier C, Vale W \& Sawchenko P 1989 Production and regulation of inhibin subunits in pituitary gonadotropes. Endocrinology 124 552-554.

Smith PF, Frawley LS \& Neill JD 1984 Detection of LH release from individual pituitary cells by the reverse hemolytic plaque assay: estrogen increases the fraction of gonadotrophs responding to GnRH. Endocrinology 115 2484-2486.

Vale W, Rivier J, Vaughen J, McClintock R, Corrigan A, Woo W, Karr D \& Spiess J 1986 Purification and characterization of an FSH releasing protein from porcine ovarian follicular fluid. Nature 321 776-779.

Ying S 1988 Inhibins, activins, and follistatins: gonadal proteins modulating the secretion of follicle-stimulating hormone. Endocrine Reviews 9 267-293.

Yokoyama Y, Nakamura T, Nakamura R, Irahara M, Aono T \& Sugino H 1995 Identification of activins and follistatin proteins in human follicular fluid and placenta. Journal of Clinical Endocrinology and Metabolism 80 915-921.

Received 28 September 1998
Accepted 14 January 1999 